\title{
Result Clauses in Modern Greek and Spanish: A Contrastive Study ${ }^{1}$
}

\author{
Antonio R. Revuelta Puigdollers \\ Universidad Autónoma de Madrid \\ antonio.revuelta@uam.es
}

\section{Abstract}

This paper examines the behaviour of result subordinators in Modern Greek and Spanish. Apart from the more frequently studied subordinators ( $\pi$ ov and $\omega \sigma \tau \varepsilon$ ) the research includes others, such as $\mu \varepsilon \alpha \pi$ o $\varepsilon \dot{\lambda} \lambda \varepsilon \sigma \mu \alpha v \alpha$ and o ó $\tau \varepsilon$, which have received little or no attention until now. The article discusses how the choice of subordinator affects the selection of mood (indicative or subjunctive), the scope of negation and interrogation, the presence or absence of correlative intensifiers in the main clause, and the clause layer the subordinate clause can operate upon (SoA, proposition, speech act).

\section{Introduction}

Most grammars on Modern Greek and Spanish concentrate on a limited range of result subordinators. ${ }^{2}$ The purpose of this paper is to extend the number of subordinators and to study their differences in behaviour. Apart from $\pi$ ov and $\omega \sigma \tau \varepsilon$ (the most frequently studied subordinators), Modern Greek has other connectors that are used to express consequence, while Spanish exhibits the subordinator por lo que/cual, (which has not received much attention either)

\footnotetext{
1 For the grant I enjoyed during 2009 I would like to express my gratitude to the Alexander S. Onassis Public Benefit Foundation. This paper has been written within the frame of the research project "Funciones y marcas del griego moderno" (HUM2007-61974) financed by the Spanish Ministry of Science and Innovation. I want to express my gratitude to $\mathrm{H}$. Ferguson for making my English more understandable.

2 For result subordinators in Spanish see Álvarez (1995, 1999); for the Greek data see Holton et alii (1997: 465), Cleris, Ch. \& Babiniotis, G. et alii (1998-2001 II 2: 107-110), Mackridge (1985: 256, 272-273), Tzartzanos (1963 B: 94-96) and AKN.
}

\section{(cc) BY-NC-ND}


in addition to que and de manera/modo que (the most frequently studied), as examples 1 and 2 show: ${ }^{3}$

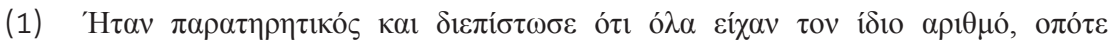

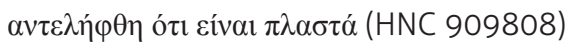

'Era observador y constató que todos llevaban el mismo número, por lo que se dio cuenta de que eran falsos'

'He was a good observer and noticed that all of them had the same number, and therefore he realized that they were false'

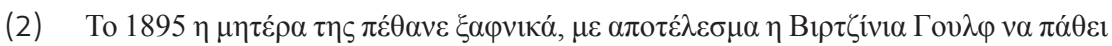

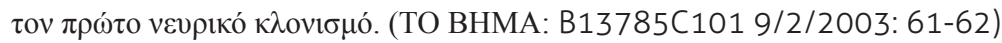

'En 1895 su madre murió de repente y a consecuencia de ello Virginia Woolf sufrió su primera crisis nerviosa'

'In 1985 her mother suddenly died, and as a consequence Virginia Wolf suffered her first nervous breakdown'

In this paper I am going to concentrate on the behaviour of all of these result

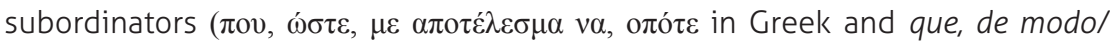
manera que, por lo cual/que in Spanish) as regards mood, negation, interrogation, the presence of correlative intensifiers and the level of the clause. ${ }^{4}$

\section{Mood Selection}

As for mood, result clauses seem to present three possible constructions: a) they can exhibit the moods of declarative independent sentences: indicative and conditional (potential and counterfactual); b) they can exhibit subjunctive. In the following sections I will examine the combination of the subordinators with these different moods. ${ }^{5}$

3 Most Greek examples are taken from the Hellenic National Corpus (HNC) developed by the Institute for Language and Speech Processing. The Spanish examples are my own or translations of the Greek examples.

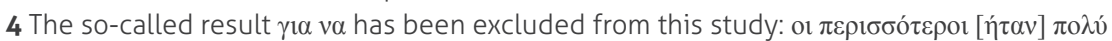

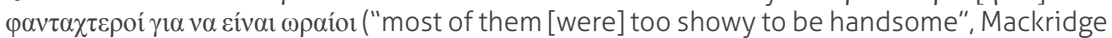
$1985,293)$. This is a special purpose clause. For this use see Mackridge (1985: 293-294), Tzartzanos (1963 B: 139) and Veloudis (2010: 287). I thank the unknown reviewer for reminding me of this construction.

5 For mood in Spanish and Greek see Revuelta (2011); for the Spanish data see Pérez Saldanya (1999); for Greek see Hesse (2003). See also the references mentioned in note 1. 


\section{1. $\Omega \sigma \tau \varepsilon$ (de manera/modo que)/ $\pi$ ov (que)}

\subsubsection{Indicative and Conditional}

Greek $\omega \sigma \tau \varepsilon$ and $\pi$ ov and Spanish de manera/modo que and que can take the moods of declarative sentences. Indicative shows that the content of the subordinate clause is an actual consequence of the main clause:

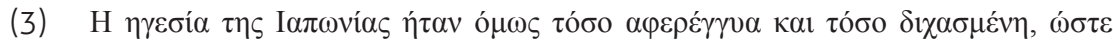

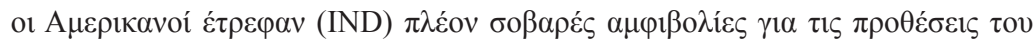
Тókı. (HNC 77277)

'The Japanese leadership was so unreliable and so split that the Americans had serious doubts about Tokyo's intentions'

a. The Japanese leadership was very unreliable and very split (main)

b. The Americans had serious doubts about Tokyo's intentions (subordinate)

(4) Era tan malo que lo odiaban (IND)

'He was so evil that they hated him'

a. He was evil (main)

b. They hated him (subordinate)

Conditional, on the other hand, points out that the content of the subordinate clause is either a potential (see 'POT' in example 5) or counterfactual (see 'COUNTER' in example 6) consequence:

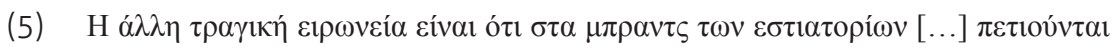

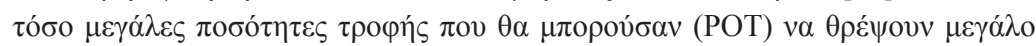

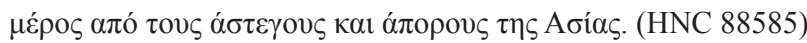

'La otra ironía es que en los brunch de los restaurantes [...] se tiran cantidades de alimento tan grandes que podrían (POT) alimentar a una gran parte de los sin techo y necesitados de Asia'

'The other irony is that the amount of food that is thrown away from restaurant brunches is so huge that it could feed a large part of Asia's homeless and needy people'

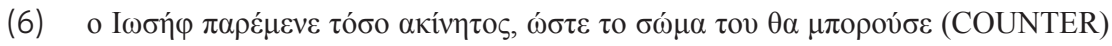

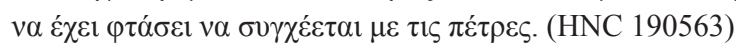

'Joseph se quedó tan inmóvil que su cuerpo podría (COUNTER) haber llegado a confundirse con las piedras'

'Joseph remained so still that his body could have been confused with the rocks' 


\subsubsection{Subjunctive}

Subjunctive is selected as mood when the consequence is not a real, but a possible consequence. The speaker does not commit to the truth of the state of affairs. That is to say, the sentence expresses uncertainty (the consequence may or may not take place). Spanish usually replaces the subordinators with como para (como para plus infinitive or como para que plus subjunctive). When the subjects of both main and subordinate clause are co-referential the subjunctive is replaced by the infinitive:

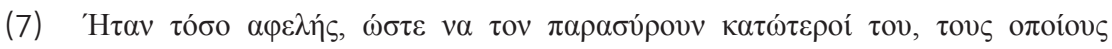
$\varepsilon \mu \pi ı \tau \varepsilon v o ́ \tau \alpha v$. (HNC 1702458)

'Era tan ingenuo como para que le engañaran (SUBJ) sus subordinados, en los que confiaba'

'He was so naive that his subordinates, whom he trusted, could fool him'

a. He was (main)

b. Perhaps his subordinates fooled him (subordinate).

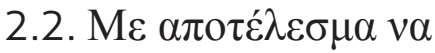

The Greek construction $\mu \varepsilon \alpha \pi$ o $\varepsilon \dot{\lambda} \lambda \varepsilon \sigma \mu \alpha$ v $\alpha$ takes only the subjunctive, but unlike previous cases the construction always introduces factive consequences: the result is taken for granted in all circumstances, and therefore the Spanish translation in these cases demands the indicative. There is no exact equivalent in Spanish, and usually the best translation is to coordinate both clauses and add a consecuencia de ello ('as a consequence') as a connector to explicitly state the relationship between both states of affairs:

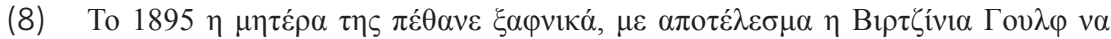

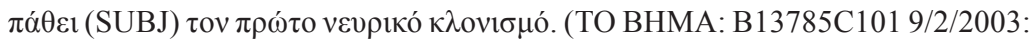
61-62)

'En 1895 su madre murió de repente y a consecuencia de ello Virginia Woolf sufrió (IND) su primera crisis nerviosa'

'In 1985 her mother suddenly died, and as a consequence Virginia Wolf suffered her first nervous breakdown.'

a. Her mother suddenly died (main)

b. Virginia Wolf suffered her first nervous breakdown (subordinate)

This "anomalous" behaviour of the subjunctive in Greek remains to be explained. Nevertheless, the mere fact that there is no possibility of using the indicative clarifies that the subjunctive mood can have a factive interpretation. 
The use of subjunctive in factive subordinates is common in Spanish in other contexts (for example in complement sentences), but not in Modern Greek. ${ }^{6}$

\subsection{Oлó $\varepsilon$ / por lo que/por lo cual}

The subordinators o $\pi$ ó $\varepsilon$ and por lo que/por lo cual can take the moods of main declarative sentences (indicative and conditional), but subjunctive is excluded:

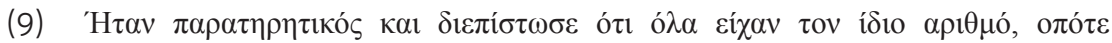

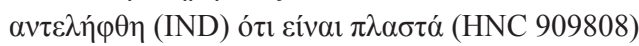

'Era observador y constató que todos llevaban el mismo número, por lo que se dio (IND) cuenta de que eran falsos'

'He was a good observer and noticed that all of them had the same number, and therefore he realized that they were false'

a. He was a good observer and noticed that all of them had the same number (main)

b. He realized that they were false (subordinate)

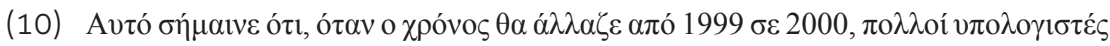

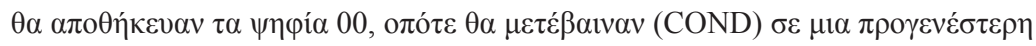

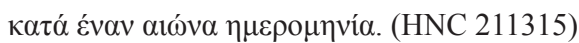

'Esto significa que, cuando el tiempo cambiara de 1999 a 2000, muchos ordenadores almacenarían los dígitos 00, por lo que entrarían (COND) en una fecha anterior en un siglo.'

'This means that, when the date would change from 1999 to 2000, many computers would record the digits 00 , and therefore they would enter into a date one century before.'

\subsection{Mood: General View}

The following table summarizes the differences and similarities of the subordinators as far as mood is concerned.

6 See Ridruejo (1999: 3229-3233) for the use of subjunctive in Spanish factive complement clauses. In these factive contexts Modern Greek selects $\pi$ ov plus indicative: see Christidis (1981) and Roussou (2006). For a recent discussion of the subjunctive, see the articles in Lingua 119 and a summary in Quer (2009). 
Table 1.

Mood restrictions.

\begin{tabular}{|c|c|c|c|c|}
\hline \multicolumn{2}{|c|}{ Subordinator } & \multirow{2}{*}{$\begin{array}{c}\begin{array}{c}\text { Indicative } \\
\text { (Real) }\end{array} \\
+\end{array}$} & \multirow{2}{*}{\begin{tabular}{|c}
$\begin{array}{c}\text { Conditional (Potential/ } \\
\text { Counterfactual: } \Theta \alpha \\
+ \text { past) }\end{array}$ \\
+ \\
\end{tabular}} & \multirow{2}{*}{$\begin{array}{c}\text { Subjunctive } \\
\text { (Spanish Infinitive with } \\
\text { co-referential subjects) } \\
+ \text { (Uncertainty) }\end{array}$} \\
\hline \multirow{2}{*}{ Class I } & $\pi$ ov/que & & & \\
\hline & $\omega ́ \sigma \tau \varepsilon /$ de manera que & + & + & + (Uncertainty) \\
\hline Class II & $\mu \varepsilon \alpha \pi \circ \tau \varepsilon ́ \lambda \varepsilon \sigma \mu \alpha \alpha \alpha / \varnothing$ & & & + (Factuality) \\
\hline Class III & оло́ $\varepsilon /$ por lo cual/que & + & + & \\
\hline
\end{tabular}

All subordinators allow the use of indicative and conditional (potential or counterfactual) both in Greek and Spanish, except $\mu \varepsilon \alpha \pi$ o $\varepsilon \dot{\lambda} \varepsilon \varepsilon \sigma \mu \alpha \nu \alpha$, which demands only subjunctive.

The subjunctive can appear with all of them except o $\pi$ ó $\varepsilon$. In Spanish the subjunctive always expresses uncertainty; this applies to Greek too, except for the subordinator $\mu \varepsilon \alpha \pi$ o $\varepsilon \dot{\varepsilon} \varepsilon \varepsilon \sigma \mu \alpha v \alpha$, which always exhibits a factual interpretation.

As a consequence, in Greek it is possible to distinguish three classes of result subordinators according to their mood.

\section{Scope of Negation}

Negation allows us to further distinguish the behaviour of the subordinators. In the following subsections I will investigate how the negation of the main clause affects the main clause itself and its subordinate clause. ${ }^{7}$

\section{1. Пov / que}

Under negation of the main clause the subordinators $\pi$ ov and que mandatorily take subjunctive. In Spanish the subjunctive is replaced by the infinitive when the subjects of both main and subordinate clause are co-referential. In both languages the negation of the main clause additionally affects the content of the subordinate clause, as the paraphrases of example 11 show (see b):

7 For negation scope in Spanish and Greek, in result and other subordinate clauses see Revuelta (2011). 


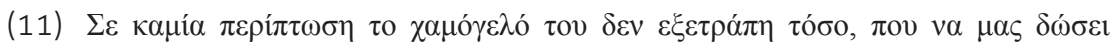

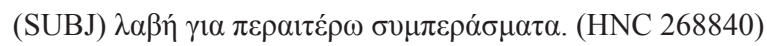

'En ningún caso su sonrisa fue tan excesiva como para darnos (INF) motivo a ulteriores conclusiones'

'In no case was his smile so broad as to give us a reason to come to further conclusions'

a. His smile was not broad (main: negative)

b. He did not give us a reason to come to further conclusions (subordinate: negative)

Since the main clause, which is the natural cause of the result clause, does not take place, the event referred to by the subordinate clause does not take place either. The subordinate clause seems to be within the scope of the negation and is affected by it. The choice of subjunctive in the subordinate clause (in Spanish subjunctive or infinitive) reflects this fact.

Apart from selecting infinitive when subjects in the subordinate and main clauses are co-referential, Spanish has the particularity that the subordinator most frequently chosen under negation is como para (como para que plus Subjunctive or como para plus Infinitive) rather than que.

\section{2. ' $\sigma \tau \varepsilon$ / de manera/modo que (como para)}

Under negation $\omega \sigma \tau \varepsilon$ allows the interpretation of the subordinate clause both within and out of the scope of the negation.

As in the previous cases, the content of the subordinate clause can be within the scope of the negation and can be affected by it (see $b$ in the examples below). The mood has to be subjunctive (infinitive in Spanish when the subjects are co-referential):

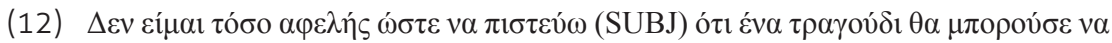

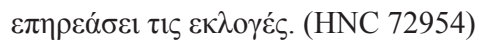

'I am not so naive as to think that a song could influence the elections'

a. I am not so naive (main: negative)

b. I do not think that a song could influence the elections (subordinate: negative)

(13) No era tan malo como para que lo odiasen (SUBJ)

'He was not so evil as to be hated by them'

a. He was not so evil (main: negative)

b. He was not hated by them (subordinate: negative) 
When the subordinate clause is negative, the negation is cancelled by the main clause's negation, since two negations are equivalent to a positive assertion, as in the example below:

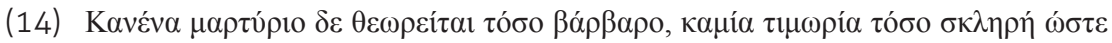

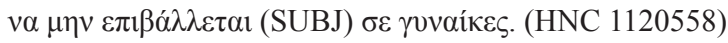

'Ningún tortura es considerada tan bárbara, ningún castigo tan duro como para que no se aplique (SUBJ) a las mujeres'

'No torture is considered so savage, no punishment so hard that it cannot be applied to women'

a. No torture is considered so savage, no punishment so hard (main: negative)

b. All tortures (= no no torture), all punishments can be applied to women (subordinate: positive)

As with the previous subordinator (see $\pi \mathrm{ov}$ ), apart from selecting infinitive when subjects in the subordinate and main clauses are co-referential, Spanish has the particularity that the subordinator most frequently used is como para (como para que plus Subjunctive / como para plus Infinitive). The subordinator de manera/modo que cannot be used in these cases.

But the subordinator $\omega \sigma \tau \varepsilon$ - and de manera/modo que in Spanish-can have a second construction. It may fall out of the scope of the negation and refer to the positive result of a negative cause. The mood selected in this case is either indicative or conditional, but subjunctive is excluded:

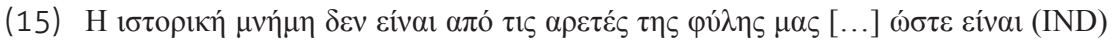

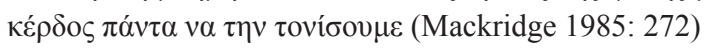

'A historical memory is not one of the virtues of our race [...] so that it is always profitable to stress it'

a. A historical memory is not one of the virtues of our race (main: negative)

b. It is always profitable to stress it (subordinate: positive)

(16) No era tan malo, de modo que lo amaban (IND)

'He was not that evil, so they loved him'

a. He was not that evil (main: negative)

b. They loved him (subordinate: positive)

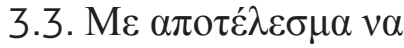

The subordinator $\mu \varepsilon \alpha \pi$ o $\varepsilon \dot{\varepsilon} \varepsilon \sigma \mu \alpha$ v $\alpha$ always falls out of the negation's scope. It always expresses the positive result of a negative cause, but the mood is subjunctive despite its factive sense: 


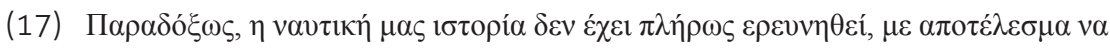

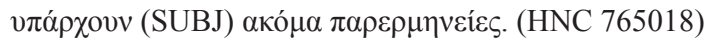

'Paradójicamente, nuestra historia naval no ha sido investigada completamente, por lo que todavía existen (IND) interpretaciones erróneas' 'Paradoxically, our naval history has not been completely researched, and as a consequence there are still many wrong interpretations'

a. Our naval history has not been researched yet (main: negative)

b. There are still many wrong interpretations (subordinate: positive)

Only when explicitly negated by $\mu$ í(v), does the subordinate clause express a negative consequence, as in the following example:

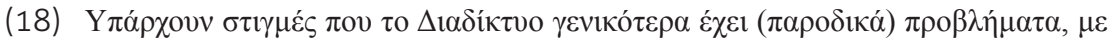

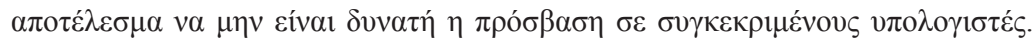
(HNC 206734)

'Hay momentos en los que Internet en general tiene (ocasionales) problemas y como resultado de ello no es posible el acceso a determinados ordenadores' 'There are times when the internet has (temporary) problems, and as a consequence there is no access to certain computers'

\subsection{Oлó $\varepsilon$ / por lo que/cual}

The same applies to o $\pi$ ó $\varepsilon$ in Greek and por lo cual / por lo que in Spanish. Their content is always out of the scope of the negation and they likewise express the positive result of the negative event referred to by the main clause. Like $\omega \sigma \tau \varepsilon$ and de manera/modo que they exclude subjunctive:

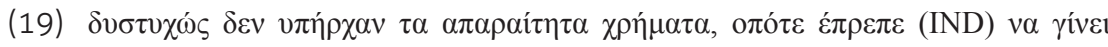

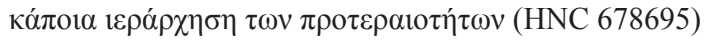

'Desgraciadamente no había el dinero necesario, por lo que hubo (IND) que ordenar las prioridades'

'Unfortunately there was not enough money, and as a consequence it was necessary to establish priorities'

a. There was not enough money

b. It was necessary to establish priorities

Only when explicitly negated, can the subordinate clause be negative, as in the following example:

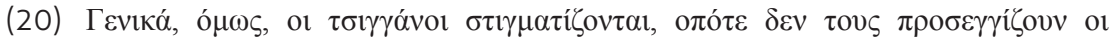

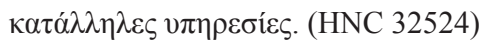


'Generalmente, sin embargo, los gitanos están estigmatizados, por lo que los servicios adecuados no se acercan a ellos'

'Generally, however, Gypsies are stigmatized, and for that reason appropriate agencies do not approach them'

\subsection{Negation: General View}

The following table gives a general view of both the scope of the main clause's negation and the interplay of the scope of negation with mood selection.

Table 2.

Negation scope and mood restrictions.

\begin{tabular}{|c|c|c|c|}
\hline Class & Subordinator & Negation & Mood \\
\hline 1 & $\pi$ ov / que & inside & subjunctive (uncertainty) \\
\hline \multirow{2}{*}{ II } & \multirow{2}{*}{$\omega ́ \sigma \tau \varepsilon /$ de manera/modo que } & inside & subjunctive (uncertainty) \\
\hline & & outside & indicative, conditional \\
\hline \multirow{2}{*}{ III } & $\mu \varepsilon \alpha \pi \mathrm{o} \varepsilon \dot{\lambda} \lambda \varepsilon \sigma \mu \alpha$ v $\alpha$ & outside & subjunctive (factuality) \\
\hline & oлó $\varepsilon \varepsilon$, por lo cual/que & outside & indicative, conditional \\
\hline
\end{tabular}

When within the scope of negation, the subordinate clause takes subjunctive: the subjunctive reflects the fact that the subordinate clause is affected by the negation and its state of affairs is supposed to not take place. Only $\mu \varepsilon \alpha \pi \circ \tau \varepsilon \dot{\lambda} \overline{\varepsilon \sigma \mu \alpha}$ $v \alpha$ behaves differently from the other subordinators, since it expresses factuality and not uncertainty, and it is out of the scope of negation.

According to their behaviour under negation, the subordinators can be placed into three different classes, which differ from those established by mood selection.

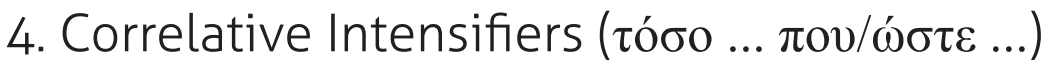

Some subordinate clauses express that the consequence is the result of the degree to which the main clause's state of affairs takes place. This degree is conveyed by correlative intensifiers, which can modify nominal phrases, adjectives, adverbs or verbs in the main clause, and are combinable only with certain subordinators, as the table below shows:

It is important to distinguish between intensifiers-such as those in the table-and complex subordinators such as de manera/modo que. Correlative intensifiers can be placed in different positions within the main clause and 
are not rigidly attached to the subordinator. On the other hand, in many cases complex subordinators are made up of a former intensifier (e.g., de manera) and a subordinator (e.g., que) from a diachronical point of view, but synchronically they behave as indivisible units (de manera/modo que are not separable).

Table 3.

Correlative intensifiers allowed by the subordinators.

\begin{tabular}{|c|c|c|c|c|c|}
\hline \multirow[t]{2}{*}{ Correlative intensifier } & \multirow[t]{2}{*}{ Subordinator } & \multicolumn{4}{|c|}{ Modified constituent } \\
\hline & & NP & Adj & Adv & Verb \\
\hline غ́ंбı / así/tan ('so') & $\pi \mathrm{ov} / \omega \sigma \tau \varepsilon /$ que & & + & + & $+(?)$ \\
\hline 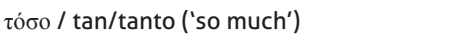 & $\pi \mathrm{ov} / \omega \dot{\sigma \tau \tau} /$ que & & + & + & + \\
\hline 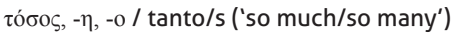 & $\pi \mathrm{ov} / \omega \dot{\sigma} \tau \varepsilon /$ que & + & & & \\
\hline 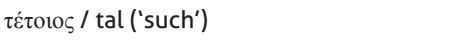 & $\pi \mathrm{ov} / \omega \dot{\sigma} \sigma \varepsilon /$ que & + & & & \\
\hline Cada ('such', lit. 'every') & que & + & & & \\
\hline 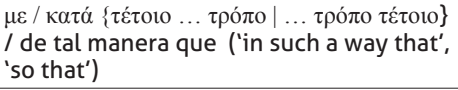 & $\pi \mathrm{ov} / \omega \dot{\sigma \tau \varepsilon / \text { que }}$ & & & & + \\
\hline $\begin{array}{l}\varepsilon 1 \varsigma \tau \rho o ́ \pi \text { ㅇ } \omega \sigma \tau \varepsilon \text { / de tal manera que ('in } \\
\text { such a way that') }\end{array}$ & $\pi \mathrm{ov} / \omega \dot{\sigma \tau \varepsilon / \text { que }}$ & & & & + \\
\hline $\begin{array}{l}\sigma \tau o \beta \beta \theta \mu \text { ó / hasta el punto/tal punto ('in } \\
\text { such a degree that') }\end{array}$ & $\pi$ ov/que & & & & + \\
\hline
\end{tabular}

\subsection{Use of Correlative Intensifiers}

The use of intensive antecedents or correlative intensifiers is limited in Greek to the subordinate clauses headed by $\pi$ ov and $\omega \sigma \tau \varepsilon$, and in Spanish to those headed by que and como para. In the case of $\pi$ ov and que their presence is compulsory:

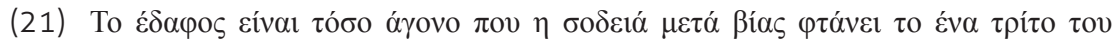
каvovikov́. (HNC 29791)

'El suelo es tan improductivo que la cosecha con dificultad llega a un tercio de lo ordinario.'

'The soil is so unproductive that the crop hardly reaches a third of the usual.'

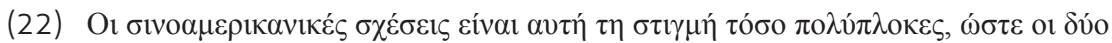

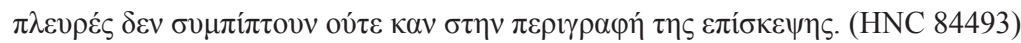
'Las relaciones chinoamericanas son en este momento tan complejas que las dos partes no coinciden ni siquiera en la descripción de la visita.'

'The Chinese-American relationship is so complex right now that both sides do not even agree on the assessment of the visit.' 


\subsection{Lack of Correlative Intensifier}

The absence of antecedent is optional with $\omega \sigma \tau \varepsilon$ and compulsory with $\mu \varepsilon$

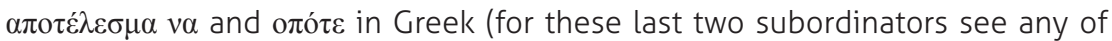
the examples in previous sections) and de manera/modo que and por lo cual/ que in Spanish:

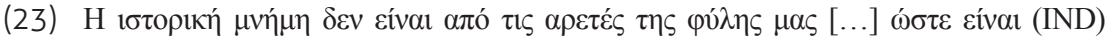

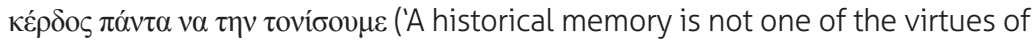
our race [...] so that it is always profitable to stress it', Mackridge 1985: 272)

(24) No era malo, de modo que lo amaban (IND) ('He was not bad, so that they loved him')

\subsection{Correlative Intensifiers: General View}

The combinability with antecedents allows us to classify the subordinators into three different categories. One subordinator ( $\pi \circ \mathrm{ov}$ ) demands the compulsory presence of

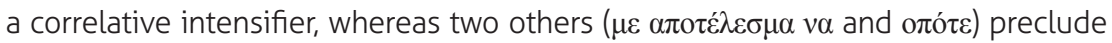
the use of such a constituent. Only $\omega \sigma \tau \varepsilon$ allows both their presence and absence.

Table 4.

Restrictions on correlative intensifiers in main sentence.

\begin{tabular}{|c|c|c|c|}
\hline \multirow{2}{*}{ Class } & \multicolumn{2}{|c|}{ Subordinator } & Correlative intensifier \\
\hline I & $\pi \circ v$ & que & + \\
\hline \multirow{2}{*}{ II } & \multirow{2}{*}{$\omega \sigma \tau \varepsilon$} & & + \\
\cline { 2 - 4 } & $\mu \varepsilon \alpha \pi \circ \tau \varepsilon ́ \lambda \varepsilon \sigma \mu \alpha \nu \alpha$ & de manera/modo que & - \\
\hline \multirow{2}{*}{ III } & оло́ $\tau \varepsilon$ & por lo que/cual & - \\
\cline { 2 - 4 } & \multicolumn{2}{|c}{} \\
\hline
\end{tabular}

\section{Level of the Clause}

The level of the clause and the type of entity put into relationship by the subordinators (states of affairs, propositions, speech acts) is another factor that has to be taken into account when classifying clauses. ${ }^{8}$ For example, clauses headed

8 See Dik \& Hengeveld (1997) for the levels and layers of the clause. 


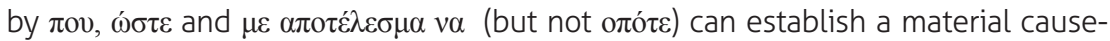
consequence connection between the states of affairs (henceforth SoAs) referred to by the main and subordinate clause: the SoA (a second order entity) in the main clause is a possible cause of the SoA described by the subordinate clause:

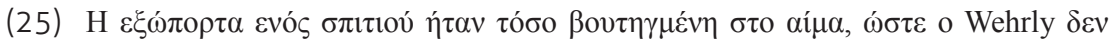

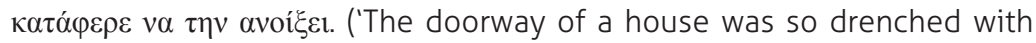
blood that Wehrly failed to open it', HNC 412739)

In other cases the main clause of $\omega ́ \sigma \tau \varepsilon$ and o $\pi$ ó $\varepsilon$ (but not of $\pi$ ov nor $\mu \varepsilon$ $\alpha \pi \mathrm{o} \varepsilon \lambda \varepsilon \sigma \mu \alpha \nu \alpha$ ) expresses not the cause, but rather the reason why a decision is taken, as in the following example:

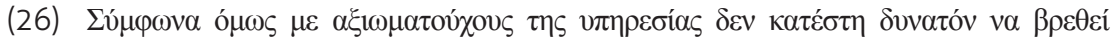

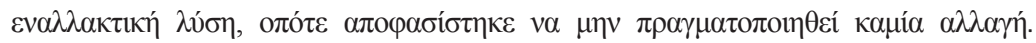
('According to some officers of the service it was impossible to find an alternative solution, and for that reason it was decided to make no change', HNC 17088)

On the other hand, $\omega \sigma \tau \varepsilon$ and o ó $\tau \varepsilon$ can establish relationships between the propositional content conveyed by both sentences (propositions are third order entities). ${ }^{\text {In }}$ the following example the first sentences are presented as the evidence from which the speaker draws the conclusion expressed by the clause headed by оло́ $\varepsilon:$

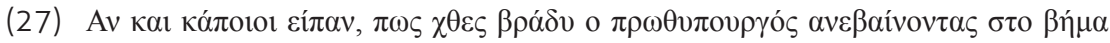

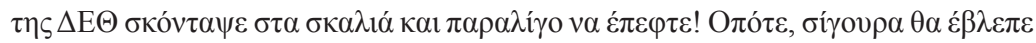

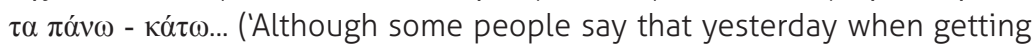
on the platform the Prime Minister tripped over the steps and nearly fell down! Therefore he would see everything upside down', HNC 661819)

In a fourth level there are cases where $\omega \sigma \tau \varepsilon$ or o $\pi$ ó $\varepsilon$ express that the speaker's speech act (and not its content or SoA) is a reaction to or a consequence of something previously said by his/her interlocutor:

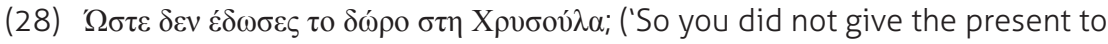
Chrysoula?', Holton et alii 465)

9 See Mackridge (1985: 272-273). Although he speaks of 'logical consequence' he refers to consequences in the SoA level that establish a reason-result consequence rather than a material cause-result consequence. 
In these last two cases, when the relationships are established between propositions or speech acts, the connectors appear rather at the beginning of an independent clause and work rather as discourse markers and not as subordinators. This fact is sometimes reflected in the punctuation, and the connectors appear after a full stop, but this is not always the rule.

The following table depicts this situation.

Table 5.

Sentence entity affected by the result clause.

\begin{tabular}{|c|c|c|c|c|c|}
\hline Class & \multicolumn{2}{|c|}{ Connector } & Status & Relationship & Level \\
\hline \multirow{2}{*}{ I } & $\pi \mathrm{ov}$ & que & subordinator & $\begin{array}{l}\text { material cause- } \\
\text { consequence }\end{array}$ & SoA \\
\hline & $\mu \varepsilon \alpha \pi \mathrm{\alpha} \delta \dot{\lambda} \lambda \varepsilon \sigma \mu \alpha \nu \alpha$ & & subordinator & $\begin{array}{l}\text { material cause- } \\
\text { consequence }\end{array}$ & SoA \\
\hline \multirow{4}{*}{ II } & \multirow{4}{*}{$\omega ́ \sigma \tau \varepsilon$} & \multirow{4}{*}{$\begin{array}{c}\text { que / de } \\
\text { manera/modo } \\
\text { que }\end{array}$} & \multirow{2}{*}{ subordinator } & $\begin{array}{l}\text { material cause- } \\
\text { consequence }\end{array}$ & So $A$ \\
\hline & & & & reason & SoA \\
\hline & & & \multirow{2}{*}{$\begin{array}{c}\text { subordinator/ } \\
\text { discourse marker }\end{array}$} & evidence & Proposition \\
\hline & & & & reaction & Speech act \\
\hline \multirow{3}{*}{ III } & \multirow{3}{*}{ о $\pi$ ó $\varepsilon$} & \multirow{3}{*}{ por lo que/cual } & subordinator & reason & SoA \\
\hline & & & \multirow{2}{*}{$\begin{array}{l}\text { subordinator/ } \\
\text { discourse marker }\end{array}$} & evidence & Proposition \\
\hline & & & & reaction & Speech act \\
\hline
\end{tabular}

\section{Interrogation}

Interrogation interplays with both mood choice and level of the clause. When expressing material consequence on the SoA level, result clauses headed by $\omega \sigma \tau \varepsilon, \pi \circ v$ and $\mu \varepsilon \alpha \pi \circ \tau \varepsilon \dot{\lambda} \varepsilon \sigma \mu \alpha$ v $\alpha$ can appear within the scope of interrogation. Those cases cover all uses of the last two subordinators ( $\pi$ ov and $\mu \varepsilon \alpha \pi \circ \tau \varepsilon \dot{\lambda} \lambda \varepsilon \sigma \mu \alpha$ $v \alpha$ ), but not all of the first ( $\omega \tau \tau \varepsilon)$, since, as we have seen in previous sections, $\omega \sigma \tau \varepsilon$ can introduce relationships other than material consequence:

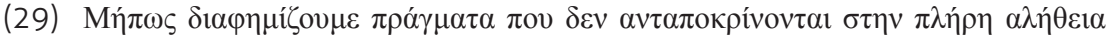

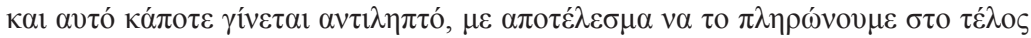

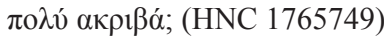

¿Acaso no estaremos publicitando cosas que no se corresponden con la verdad y ello resulta a veces perceptible y como consecuencia de ello lo pagamos al final muy caro?

'Aren't we advertising things that do not correspond with the whole truth, and this fact is perceptible, and as a consequence at the end we are paying a very high price for it?' 


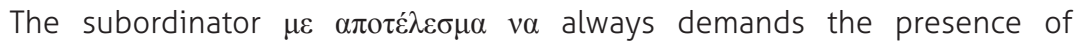
subjunctive. But interrogation may optionally trigger subjunctive in Greek when the subordinate clause is headed by $\omega \sigma \tau \varepsilon$ and $\pi$ ov; the same applies in Spanish to que and como para (que), as the following Greek examples and their translations into Spanish prove (the first example is in subjunctive and the second in indicative): ${ }^{10}$

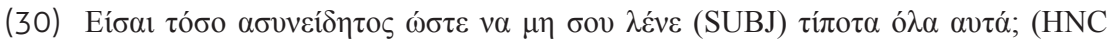
1189335)

'¿Tienes tan poca conciencia como para que no te digan (SUBJ) nada todas estas cosas?'

'Are you so lacking in scruples that all these things mean nothing to you?'

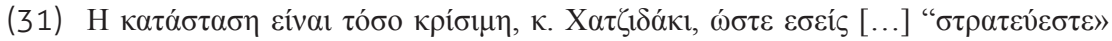

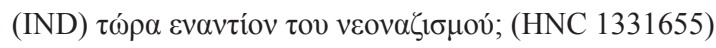

¿Es tan grave la situación, Sr. Hatzidakis, que usted [...] "milita" (IND) ahora contra el Nazismo?

'Is the situation so serious, Mr. Hatzidakis, that you [...] are now "becoming militant" against Nazism?"

In the first of the two examples (30) both the main and subordinate clauses are under interrogation and therefore there is uncertainty as to the reality of the state of affairs referred to by them. The subjunctive of the subordinate clause is a formal reflection of such an uncertainty. In the second (31) example the result is just taken for granted (indicative) and only the reason referred to by the main sentence is questioned.

Unlike the above-mentioned subordinators, о $\pi$ ó $\varepsilon$ cannot appear within interrogative sentences to express result. ${ }^{11}$ That is so because this subordinator cannot establish material cause-consequence relationships between SoAs.

On the other hand, both $\omega \sigma \tau \varepsilon$ and o ó $\tau \varepsilon$ can be out of the interrogative scope and introduce the question:

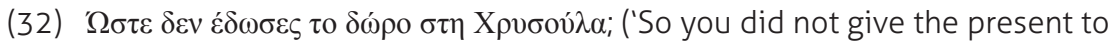
Chrysoula?', Holton et alii 465)

10 See Revuelta (2011)

11 Other uses of оло́ $\varepsilon$ are compatible with interrogation, as for example, when it means

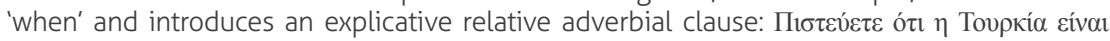

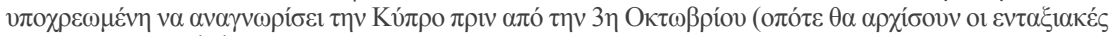

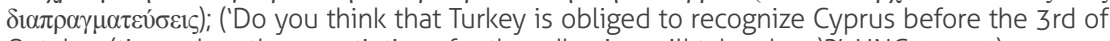
October (time when the negotiations for the adhesion will take place)?', HNC 27110). 


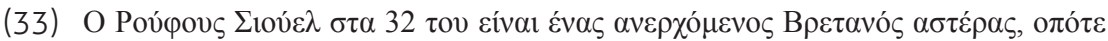

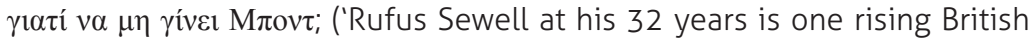
star, therefore why cannot he become Bond?', HNC 338339)

In these cases the connectors operate not on the SoA level, but on the speech act level. Subjunctive is excluded in these contexts.

The following table depicts this situation, where both the scope of interrogation and the interplay between this factor and mood choice are reflected.

Table 6.

Interrogation scope and mood restrictions.

\begin{tabular}{|c|c|c|c|c|}
\hline Class & Sub & rdinator & Interrogation's & Mood \\
\hline \multirow[t]{2}{*}{1} & $\pi \mathrm{ov}$ & que & within & $\begin{array}{l}\text { indicative, conditional, } \\
\text { subjunctive }\end{array}$ \\
\hline & 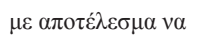 & & within & subjunctive \\
\hline \multirow[t]{2}{*}{ II } & \multirow{2}{*}{$\omega \sigma \tau \varepsilon$} & & within & $\begin{array}{l}\text { indicative, conditional, } \\
\text { subjunctive }\end{array}$ \\
\hline & & de manera/modo que & outside & indicative, conditional \\
\hline III & оло́ $\varepsilon \varepsilon$ & por lo que/cual & outside & indicative, conditional \\
\hline
\end{tabular}

\section{General View}

If we take into account all the factors analysed in this paper, we obtain a provisional classification of the Greek data such as the one depicted in the following table.

Table 7.

General view: Restrictions imposed by each subordinator.

\begin{tabular}{|c|c|c|c|c|c|}
\hline Subordinator & Mood & Negation & Intensifier & Level & Interrogation \\
\hline$\pi \mathrm{ov}$ & $\begin{array}{l}\text { IND, COND, SUB] } \\
\text { (uncertainty) }\end{array}$ & $\begin{array}{l}\text { inside } \\
\text { (SUBJ) }\end{array}$ & + & $\begin{array}{c}\text { material } \\
\text { cause- } \\
\text { consequence }\end{array}$ & inside \\
\hline$\omega \sigma \tau \tau \varepsilon$ & $\begin{array}{l}\text { IND, COND, SUB] } \\
\text { (uncertainty) }\end{array}$ & $\begin{array}{c}\text { inside } \\
\text { (SUBJ), } \\
\text { outside } \\
\text { (IND, COND) }\end{array}$ & $+1-$ & $\begin{array}{l}\text { material } \\
\text { cause- } \\
\text { consequence, } \\
\text { reason- } \\
\text { consequence, } \\
\text { evidence, } \\
\text { reaction }\end{array}$ & inside /outside \\
\hline$\mu \varepsilon \alpha \pi \mathrm{\alpha} \varepsilon \dot{\lambda} \overline{\varepsilon \sigma} \mu \alpha \alpha \alpha$ & SUBJ (factuality) & $\begin{array}{l}\text { outside } \\
\text { (SUBJ) }\end{array}$ & - & $\begin{array}{c}\text { material } \\
\text { cause- } \\
\text { consequence }\end{array}$ & inside \\
\hline оло́ $\tau \varepsilon$ & IND, COND & $\begin{array}{c}\text { outside } \\
\text { (IND, COND) }\end{array}$ & - & $\begin{array}{l}\text { reason- } \\
\text { consequence, } \\
\text { evidence, } \\
\text { reaction }\end{array}$ & outside \\
\hline
\end{tabular}


The table considers the behaviour of the subordinators within the different contexts and the interplay among them.

As we have seen, negation correlates with a second factor, the mood: when the subordinate clause is within the scope of the main clause's negation, subjunctive is required; when the subordinate clause is out of negation's scope indicative or conditional are the rule. The subordinator $\mu \varepsilon \alpha \pi$ o $\varepsilon_{\varepsilon} \lambda \varepsilon \sigma \mu \alpha \nu \alpha$ escapes this rule, because subjunctive is its only mood. The Greek data have parallel constructions in Spanish syntax.

Although not completely reflected in the table, interrogation's scope interplays with mood and sentence level: when the subordinate clause is within the scope of the interrogation, subjunctive is possible (but not when it is outside) and the relationship is established between SoAs (but not between propositions or speech acts). The presence of correlative intensifiers is restricted to the same contexts, too.

Although the table just reflects the Greek data, throughout this article many of the differences between the Greek and Spanish systems have been described. Some of these differences are the following: the lack of a subordinator like $\mu \varepsilon$ $\alpha \pi \circ \tau_{\varepsilon} \lambda \varepsilon \sigma \mu \alpha v \alpha$ in Spanish; the substitution of infinitive for subjunctive when subjects in both clauses are co-referential; the need in Spanish to replace the subordinators que and de manera/modo que with como para (infinitive or que + subjunctive) under negation in most contexts when the subordinate sentence is within the negation's scope.

One of the consequences of this asymmetry is the fact that Spaniards tend to ignore the construction $\mu \varepsilon \alpha \pi \circ \tau \varepsilon \dot{\lambda} \varepsilon \sigma \mu \alpha v \alpha$ when speaking Greek, whereas they have no difficulty learning the use of $\pi$ ov and $\omega \sigma \tau \varepsilon$. Apart from the asymmetry of both systems the lack of information in most grammars about $\mu \varepsilon \alpha \pi$ o $\varepsilon \dot{\lambda} \lambda \varepsilon \sigma \mu \alpha v \alpha$ and o $\pi$ ó $\varepsilon$ plays a fundamental role. ${ }^{12}$ On the other hand, Greek speakers tend to ignore the Spanish construction como para.

Despite the existence of previous works (Álvarez 1995, 1999) a more complete description of the Spanish data along the lines presented here is needed. Once the conditions of use of the subordinators in both languages are fully described, it will be possible to establish the correspondences between them. The present work is just a first attempt.

12 The grammar by Cleris \& Babiniotis et alii (1998-2001) is the only one that mentions this construction. 


\section{References}

Álvarez, A.I. 1995. Las construcciones consecutivas. Madrid, Arco Libros.

Álvarez, A.I. 1999. Las construcciones consecutivas. In I. Bosque and V. Demonte (eds.), vol. 3, 3739-3804.

Bosque, I. and V. Demonte (eds.) 1999. Gramática descriptiva de la lengua española. 3 vols. Madrid, Editorial Espasa.

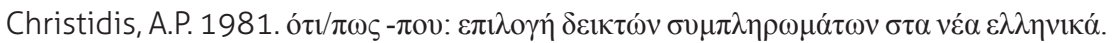
Studies in Greek Linguistics 2, 113-178.

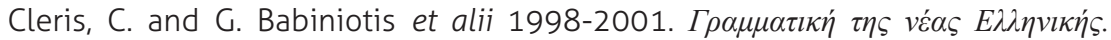

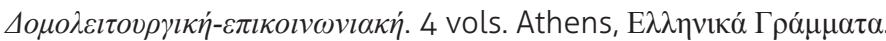

Dik, S.C. 1997. The Theory of Functional Grammar. 2 vols., ed. K. Hengeveld. Berlin, Gruyter.

Hesse, R. 2003. Syntax of the Modern Greek Verbal System. The Use of the Forms, Particularly in Combination with $\theta \alpha$ and $v \alpha$. Copenhague, Museum Tusculanum Press.

Holton, D., P. Mackridge and I. Philippaki-Warburton 1997. Greek: a comprehensive grammar of the modern language. London, Routledge.

$\Lambda K N=\Lambda \varepsilon \xi \xi$ $\Theta \varepsilon \sigma \sigma \alpha \lambda o v i k n \varsigma$, Thessaloniki.

Mackridge, P. 1985. The Modern Greek Language. Oxford, Oxford University Press.

Pérez Saldanya, M. 1999. El modo en las oraciones relativas y adverbiales. In I. Bosque and V. Demonte (eds.), vol. 2, 3253-3323. 
Quer, J. 2009. Twists of mood: The distribution and interpretation of indicative and subjunctive. Lingua 119, 1779-1787.

Revuelta Puigdollers, A.R. 2011. Causal clauses in Spanish and Modern Greek and subjunctive licensing. Studies in Greek Linguistics 31, 408-419. Thessaloniki.

Ridruejo, E. 1999. Modo y modalidad. El modo en las subordinadas sustantivas. In I. Bosque and V. Demonte (eds.), vol. 2, 3209-3251.

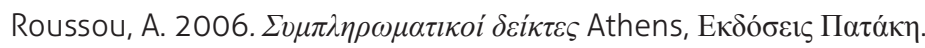

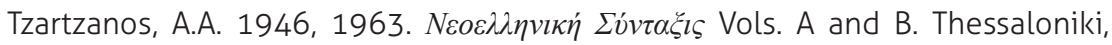

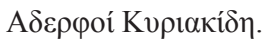

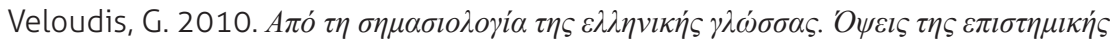

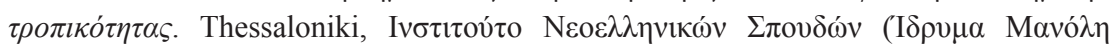

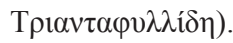


Major Trends in Theoretical and Applied Linguistics 